\title{
UPPER EOCENE CALCAREOUS NANNOFOSSIL BIOSTRATIGRAPHY: A NEW PRELIMINARY PRIABONIAN RECORD FROM NORTHERN SAUDI ARABIA
}

\author{
AlJAhDAli, M. H..$^{1 *}$ - ElHAG, M. ${ }^{2,3}-$ MufrReh, Y. ${ }^{4}-$ MEMESH, A. ${ }^{5}-$ AlSOUBHI, S. ${ }^{4}-$ \\ ZALMOUT, I. S. ${ }^{4}$ \\ ${ }^{1}$ Marine Geology Department, Faculty of Marine Sciences, King Abdulaziz University, P. O. \\ Box 80200, Jeddah 21589, Saudi Arabia \\ ${ }^{2}$ Department of Hydrology and Water Resources Management, Faculty of Meteorology, \\ Environment \& Arid Land Agriculture, King Abdulaziz University, Jeddah, 21589, Saudi \\ Arabia
}

${ }^{3}$ Department of Applied Geosciences, Faculty of Science, German University of Technology in Oman, Muscat 1816, Oman

${ }^{4}$ Saudi Geological Survey, Department of Paleontology, Jeddah, Saudi Arabia

${ }^{5}$ Saudi Geological Survey, Department of Sedimentary Geology, Jeddah, Saudi Arabia

*Corresponding author

e-mail:maljahdli@kau.edu.sa

(Received $15^{\text {th }}$ Apr 2020; accepted $10^{\text {th }}$ Jul 2020)

\begin{abstract}
The current research work represents the first calcareous nannofossil biostratigraphic record of the upper Eocene Rashrashiyah Formation in northern Saudi Arabia. The Rashrashiyah Formation is an Eocene carbonate sedimentary unit, exposed adjacent to the Jordanian border, and yielded rich and diverse nannofossil assemblages. The Rashrashiyah Formation overlies the Paleogene rocks of the Umm Wu'al Formation and is unconformably topped by the Neogene (Miocene) Sirhan Formation. Our nannofossil biostratigraphic data recognized 44 species belonging to 21 genera. These taxa indicate a Priabonian age based on the presence of Chiasmolithus oamaruensis, and the recognition of bioevents in concordance with the global Priabonian zonations. Three comparable major zones and zonal boundaries (CP14b/CP15, NP18, and CNE17) were recognized in the study section indicative of a late Eocene age. The Base common (Bc) of Reticulofenestra erbae was detected at the same level as the top of Chiasmolithus grandis, supporting the bioevent reliability in the Tethys realm. A single and more isolated occurrence of Isthmolithus recurvus was observed within Zones CP15 and NP18 at the maximum increase abundance of $R$. erbae. Our calcareous nannofossil biostratigraphy from the Rashrashiyah Formation has coincided with the assignment for units 2 and 3 of the Wadi Esh-Shallalah Formation in Qa' Faydat ad Dahikiya in the eastern desert Jordan.
\end{abstract}

Keywords: paleoecology, zonation, Arabia, bioevents, Paleogene

\section{Introduction}

Calcareous nannofossils are one of the major calcified phytoplankton that appeared and flourished in the marine photic zone since late Triassic (Gardin et al., 2012). They serve as excellent age biomarkers with wide-range correlation and sensitive indicators to trophic changes in the photic zone (Aubry, 1992; Perch-Nielsen, 1985). The Eocene epoch is one of the most significant geological times because it is characterized by a transition from a pronounced global warming to a significant large-scale glaciation (Miller et al., 1991; Pagani et al., 2005; Zachos et al., 2001). The late Eocene, therefore, 
represents a crucial climatic event of a major shift from a green-house world to the inception of the ice-house world in the early Oligocene when temperature and sea level played a major role in the distribution of marine microfossils (Miller et al., 2008; Pälike et al., 2006; Villa et al., 2008). This climatic shift, consequently, caused a profound decline in the diversity of calcareous nannofossils toward the early Oligocene (Aubry, 1992; Bown et al., 1991, 2004) and increased provincialism (i.e., different frequencies of taxa), between low- to high-latitude regions since the late Eocene (Aubry, 1992; Bahrawi and Elhag, 2016).

One of the major obstacles in understanding the late Eocene dynamics is that the Bartonian/Priabonian boundary is still to be determined, although several attempts have utilized calcareous nannofossil biostratigraphy (Agnini et al., 2011; Cotton et al., 2017; Farouk et al., 2015; Strougo et al., 2013). The upper Eocene carbonate sections of marine origin are widely distributed in Jordan (Bender, 1968; Farouk et al., 2015; Mustafa and Zalmout, 2002; Zalmout et al., 2000), Syria (Krasheninnikov et al., 1996), and Egypt (Strougo et al., 2013), and the very rare outcrops in Saudi Arabia have never been investigated thoroughly. During a routine geological survey in northern Saudi Arabia, a chalky exposed section, that crops out to $\sim 10 \mathrm{~m}$, was investigated. This section belongs to the Rashrashiyah Formation, located $\sim 20 \mathrm{~km}$ south the Saudi-Jordanian boarders, and is overlain by the Sirhan Formation (text Fig. 1). Initial and tentative dating reports using echinoids and foraminifera support a late Eocene age (Meissner et al., 1990).

The aim of this study is: 1) to perform detailed calcareous nannofossil biostratigraphy which presents the first upper Eocene biostratigraphic record from Saudi Arabia, and 2) correlate local Saudi Eocene bioevents with local-regional calcareous nannofossil biostratigraphic records from Egypt and Jordan (Farouk et al., 2015; Strougo et al., 2013).

\section{Materials and methods}

\section{Geological settings of the study area}

The Sirhan Basin, also known as Azraq-Sirhan Basin (Graben/Depression/Trough), is a large scale regional synclinal structure bounds by two major faults in the northern part of the Arabian Peninsula (Fig. 1). It runs for several hundred kilometers from the Eastern Desert of Jordan through northern Saudi Arabia (Bahrawi and Elhag, 2019; Powers et al., 1966). The northwest-southeast oriented basin is a classical Neo-Tethyan model in origin that paleogeographically bounding the northern portion of the Arabian Carbonate Platform. As a part of the Syrian Arc System (Guiraud et al., 2001), the basin was initiated as early as Late Cretaceous by major marine transgression associated with severe compression stresses and faulting; this has resulted in the deposition and accumulation of a thick belt of carbonate and mixed sediments stretching east-west for at least $300 \mathrm{~km}$ in the north part of the Arabian Peninsula (Al-Rawi, 2014; Elhag and Bahrawi, 2019). During the Early Paleogene, the Sirhan Basin was affected by the Al-Jawf Rifting event which continued to accommodate carbonate sediments and to subside in response to loading along its major axis (Guiraud et al., 2001).

The development of this basin came into a halt by the end of the Alpine Orogeny tectonic event (latest Eocene-Early Oligocene) which is marked by a major drop in sea-level and the collision of Arabia with Eurasia. Subsurface data shows that the Sirhan basin has accommodated over 6 kilometers of sediments from the Paleozoic through the Neogene (Al-Rawi, 2014). Within the Sirhan Basin, Cretaceous and Tertiary sediments are exposed, while most of the Mesozoic and Paleozoic are deeply buried (Guiraud et al., 2001). 


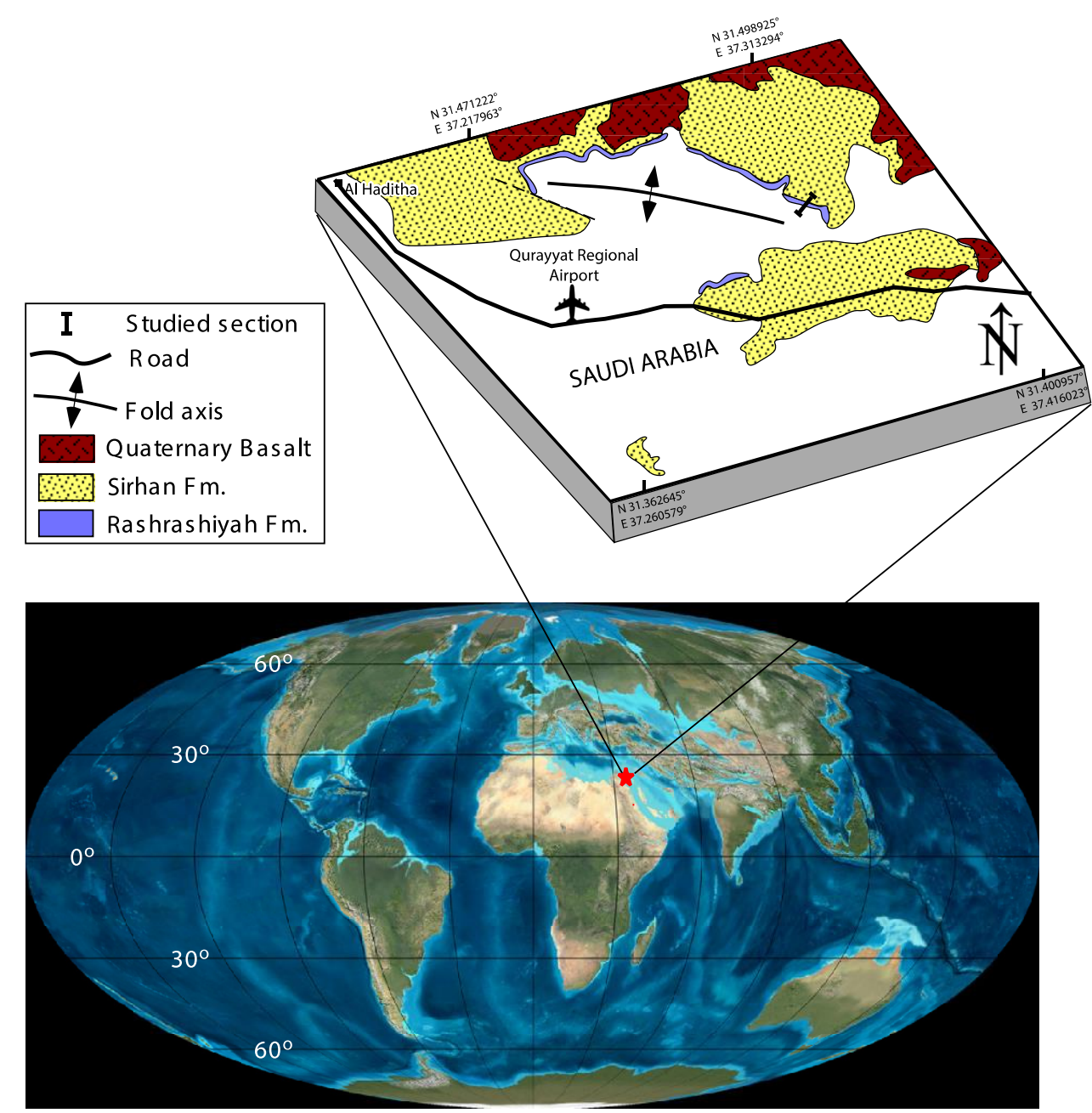

Figure 1. Map showing the geology and paleogeography around the studied section located near the Saudi-Jordanian boarders. (A) Geological map modified after Wallace et al. (1994). (B) Paleogeographical map modified of the Eocene 38 Ma created with TSCreator (Version 7.4) (https://engineering.purdue.edu/Stratigraphy/tscreator)

The Rashrashiyah Formation of Meissner et al. (1990) is part of the CretaceousPaleogene sedimentary sequence that was accommodated during the development of the Sirhan Basin (trough) in north Saudi Arabia. This formation is partially exposed within the eastern flank of the basin close and around $31^{\circ} 28^{\prime} \mathrm{N}$ and $37^{\circ} 17^{\prime} \mathrm{E}$. The total thickness of this formation from subsurface data is estimated to be $75 \mathrm{~m}$ near Al Qurayyat Water well, however, the top two-thirds of it stretch out along isolated scarps and hills in the Rashrashiyah area. Lithologically, it is composed of grayish-white, massive chalk and calcareous bituminous claystone (marl), and minor crystalline limestone beds. The lower part of the formation is dominated by gypsiferous chalk, while the middle part is composed of light-brown, calcareous claystone and hard crystalline echinoidal limestone, and the upper part is grayish-white, calcareous claystone (Halawani, 2001; Meissner et al., 1990). The base of the formation overlaps the top of the Jirani Member of the Umm Wu'al Formation. The top boundaries of the formation mark a clear contact with the base of the Sirhan Formation, where a major unconformity separates its irregular eroded most 
younger beds (and the whole Oligocene) from the Miocene and younger strata (Meissner et al., 1990).

The topmost exposed 10 meters of the section, below the clastic Sirhan Formation, were investigated and sampled in this study (Fig. 2). The cliff-forming part of the section is mostly marly and argillaceous limestones (Fig. 2). Apparently, all the Oligocene section was subjected to erosion. As mentioned earlier, the age of the Rashrashiyah Fm. was tentatively determined to employ echnoides and foraminifera data to the late Eocene (Elhag et al., 2017; Meissner et al., 1990).

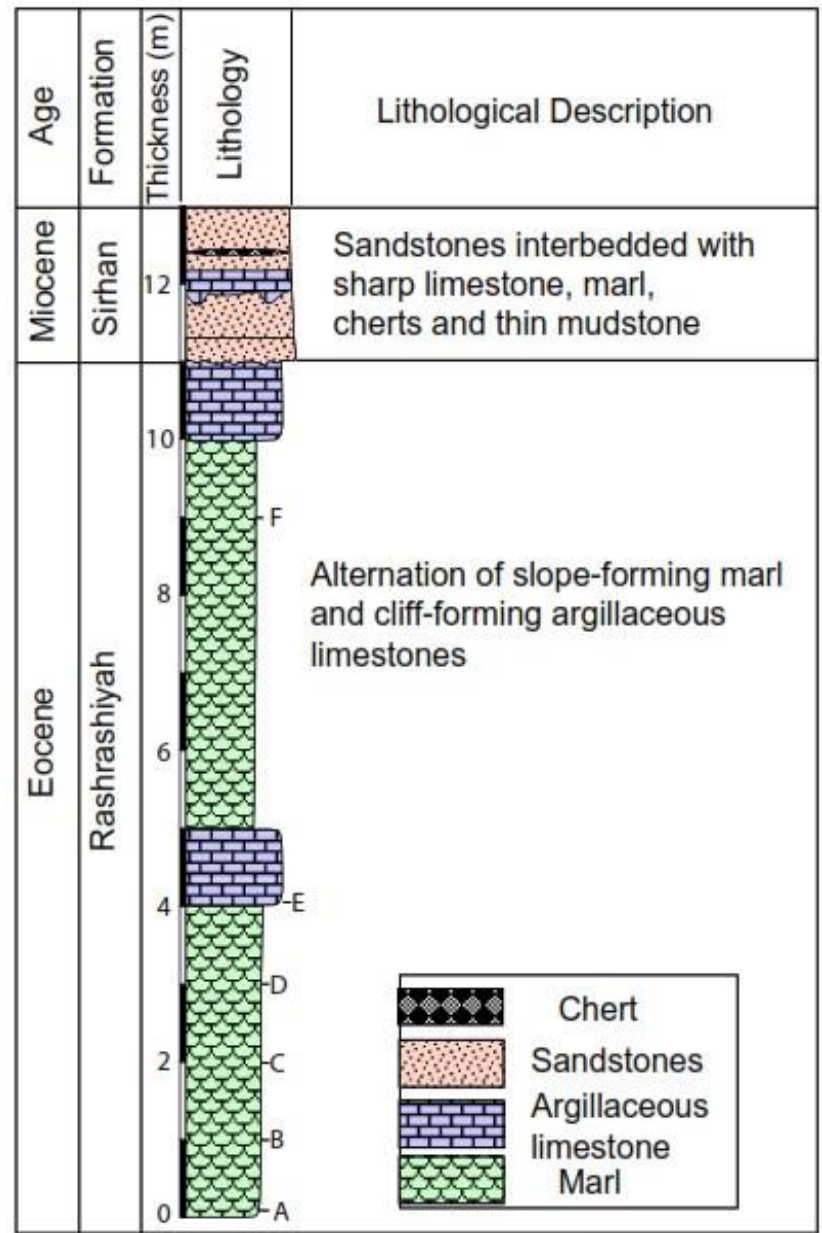

Figure 2. Lithology of the studied section representing the upper part of the Rashrashiyah Formation and the base of the Sirhan Formation. Letters A-F represents sampling levels

\section{Ground survey and identification settings}

Representative rock samples from the Rashrashiyah Formation were obtained every one-meter interval throughout the section as possible (Fig. 2). Six samples were given a prefix A-F and smear slides were prepared from freshly broken pieces of chalk based on standard techniques (Perch-Nielsen, 1985). Semi-quantitatively, at least 300 specimens were counted on random fields of view under Ziess Axiolab A1 at a magnification of $1000 \times$. To detect rare and important biomarkers, two additional long traverses of each slide were scanned to find rare taxa. Data containing raw count were converted into percentages to detect fluctuations in abundances (see Appendix A). The zonations of 
Martini (1971), Okada and Bukry (1980), and Agnini et al. (2014) were applied for detailed calcareous nannofossil biostratigraphy. Biozone boundaries were defined and followed after Agnini et al. (2014).

Identification of Paleogene calcareous nannofossil assemblages is based on the taxonomy of Perch-Nielsen (1985), Bown and Dunkley Jones (2012) and Fornaciari et al. (2010). The state of preservation of calcareous nannofossil was qualitatively evaluated as: good, moderate, or poor, in which the former shows little dissolution and/or overgrowth and the identification to the species level was achieved, while the latter has a severe effect of dissolution and/or overgrowth and identification was hardly possible to the generic/species level. The raw count was transformed into abundance codes via Bugwin (C) Software in which Abundant (A) was assigned for 11-100 species, Common (C) for 6-10 species, Few (F) for 3-5 species, and Rare (R) for 1-2 species. Species list mentioned in this study is found in Appendix $B$, while raw count, and percentages are found in Appendix A.

\section{Results}

Calcareous nannofossils are rich and highly diverse. 21 genera and 44 species were identified in the Rashrashiyah Formation in Samples A-F (Table 1). The overall state of preservation showed a pattern up section ranging between good in the lower part of the section (Sample A) to poor up section (Sample F), while it is moderate in the middle of the studied section (Sample D) (Table 1). Species richness showed a similar pattern in being high in Sample A (39 species) and gradually declined toward the top of the section in Sample F (27 species, Table 1).

Zone NP18 of Martini (1971), and Zone CNE17 of Agnini et al. (2014), while two zones CP14b and CP15 of Okada and Bukry (1980) of the upper Eocene were recognized. Zone NP18, which is defined from the base of Chiasmolithus oamaruensis to the base of Isthmolithus recurvus (Martini, 1971), has a thickness of $9 \mathrm{~m}$ covering the entire studied interval due to the presence of $C$. oamaruensis and $R$. bisecta $>10 \mu \mathrm{m}$ (Table 1). The presence of $C$. oamaruensis suggests an early Priabonian age, according to Berggren et al. (1995), for the Rashrashiyah Fm. The most common species that characterize this zone are: Chiasmolithus grandis, Chiasmolithus oamaruensis, Coccolithus formosus, Coccolithus pelagicus, Cyclicargolithus floridanus, Discoaster barbadiensis, $D$. saipanensis, $R$. bisecta, Reticulofenestra erbae, and Reticulofenestra reticulata.

Within Zone NP18, additional bioevents were recognized in samples A-F (0-9 m thickness). At the base of the section, $C$. grandis showed a rare abundance, where at Sample B $(1 \mathrm{~m})$ it marked the top event that defined the CP14b-CP15 boundary of Okada and Bukry (1980) (Fig. 3). At the same level as the top event of C. grandis, Reticulofenestra erbae substantially increased its abundance to constitute 6-8\% of the total assemblage (Fig. 3). The increase in R. erbae abundance began one sample above the base of the section and continued to Sample F $(9 \mathrm{~m})$, where species richness declined to 27 species (Fig. 3). Therefore, samples A-F lies within Zone CNE17 of Agnini et al. (2014) owing to the common interval of $R$. erbae. In Sample E (4 m), a rare occurrence ( 2 species/slide) of Isthmolithus recurvus is observed with no presence in the following Sample F (9 m) (Table 1; Fig. 3). The rare isolated single occurrence of Isthmolithus recurvus cannot confidently be utilized to mark Zone NP19 (Martini, 1971), hence, Sample F still lies within Zone NP18 and therefore CNE17 (Agnini et al., 2014). 
Table 1. Range chart of the Upper Eocene sampled calcareous nannofossils from the top 10 m of the Rashrashiyah Formation in NW Saudi Arabia

\begin{tabular}{|c|c|c|c|c|c|c|}
\hline Sample & $\mathrm{F}$ & $\mathrm{E}$ & $\mathrm{D}$ & $\mathrm{C}$ & $\mathrm{B}$ & A \\
\hline Height $(\mathrm{m})$ & 9 & 4 & 3 & 2 & 1 & 0 \\
\hline Martini (1971) & \multicolumn{6}{|c|}{ NP18 } \\
\hline Okada and Bukry (1980) & \multicolumn{4}{|c|}{ CP15 } & \multicolumn{2}{|c|}{ CP14b } \\
\hline Agnini et al. (2014) & \multicolumn{6}{|c|}{ CNE17 } \\
\hline Diversity & 27 & 33 & 33 & 29 & 36 & 39 \\
\hline Preservation & $\mathrm{P}$ & M-P & $\mathrm{M}$ & $\mathrm{G}$ & M-G & $\mathrm{G}$ \\
\hline Group Abundance & $\mathrm{C}$ & $\mathrm{A}$ & VA & VA & VA & VA \\
\hline Blackites cf. morionum & & & & & $\mathrm{R}$ & $\mathrm{C}$ \\
\hline Blackites spinosus & $\mathrm{F}$ & $\mathrm{C}$ & A & $\mathrm{F}$ & $\mathrm{F}$ & $\mathrm{F}$ \\
\hline Braarudosphaera bigelowii & $\mathrm{R}$ & $\mathrm{R}$ & & & & \\
\hline Chiasmolithus grandis & & & & & $\mathbf{R}$ & $\mathrm{R}$ \\
\hline Chiasmolithus oamaruensis & & $\mathrm{R}$ & $\mathrm{R}$ & & $\mathrm{R}$ & $\mathbf{F}$ \\
\hline Clausicoccus subdistichtus & $\mathrm{F}$ & $\mathrm{C}$ & $\mathrm{C}$ & $\mathrm{C}$ & A & $\mathrm{R}$ \\
\hline Coccolithus eopelagicus & $\mathrm{C}$ & $\mathrm{R}$ & $\mathrm{R}$ & $\mathrm{R}$ & $\mathrm{R}$ & A \\
\hline Coccolithus pelagicus & $\mathrm{A}$ & $\mathrm{A}$ & A & $\mathrm{A}$ & A & $\mathrm{F}$ \\
\hline Cruciplacolithus cruciformis & & $\mathrm{R}$ & $\mathrm{R}$ & & $\mathrm{F}$ & A \\
\hline Cyclicargolithus floridanus $<5$ & $\mathrm{~A}$ & $\mathrm{~A}$ & A & $\mathrm{A}$ & A & A \\
\hline Cyclicargolithus floridanus & $\mathrm{A}$ & $\mathrm{A}$ & A & A & A & $\mathrm{F}$ \\
\hline Discoaster barbadiensis & $\mathrm{F}$ & $\mathrm{F}$ & $\mathrm{F}$ & $\mathrm{F}$ & $\mathrm{F}$ & A \\
\hline Discoaster saipanensis & $\mathrm{F}$ & $\mathrm{F}$ & $\mathrm{A}$ & $\mathrm{C}$ & $\mathrm{C}$ & $\mathrm{R}$ \\
\hline Discoaster tanii & $\mathrm{R}$ & $\mathrm{R}$ & $\mathrm{R}$ & & & $\mathrm{R}$ \\
\hline Coccolithus formosus & $\mathrm{C}$ & $\mathrm{C}$ & $\mathrm{R}$ & $\mathrm{C}$ & $\mathrm{C}$ & $\mathrm{C}$ \\
\hline Helicosphaera bramlettii & $\mathrm{C}$ & $\mathrm{C}$ & $\mathrm{C}$ & $\mathrm{C}$ & $\mathrm{R}$ & \\
\hline Helicosphaera compacta & $\mathrm{F}$ & $\mathrm{R}$ & F & $\mathrm{R}$ & $\mathrm{R}$ & $\mathrm{R}$ \\
\hline Helicosphaera reticulata & & $\mathrm{R}$ & $\mathrm{R}$ & $\mathrm{F}$ & & \\
\hline Helicosphaera wilcoxii & & $\mathrm{R}$ & $\mathrm{F}$ & & & \\
\hline Hughesius tasmaniae & & & & & & $\mathrm{C}$ \\
\hline Isthmolithus recurvus & & $\mathbf{R}$ & & & & \\
\hline Lanternithus minutus & $\mathrm{C}$ & $\mathrm{F}$ & $\mathrm{F}$ & $\mathrm{C}$ & $\mathrm{F}$ & $\mathrm{F}$ \\
\hline Neococcolithes dubius & & & $\mathrm{F}$ & $\mathrm{R}$ & $\mathrm{R}$ & $\mathrm{F}$ \\
\hline Pedinocyclus gibbsiae & $\mathrm{F}$ & $\mathrm{F}$ & $\mathrm{C}$ & $\mathrm{F}$ & $\mathrm{C}$ & \\
\hline Pontosphaera exilis & & & & & $\mathrm{F}$ & $\mathrm{F}$ \\
\hline Pontosphaera panarium & & & & $\mathrm{R}$ & $\mathrm{R}$ & $\mathrm{R}$ \\
\hline Pontosphaera multipora & & $\mathrm{R}$ & $\mathrm{R}$ & $\mathrm{R}$ & $\mathrm{F}$ & $\mathrm{C}$ \\
\hline Reticulofenestra bisecta & $\mathrm{A}$ & $\mathrm{R}$ & $\mathrm{F}$ & & $\mathrm{C}$ & $\mathrm{F}$ \\
\hline Reticulofenestra daviesii & $\mathrm{R}$ & $\mathrm{F}$ & $\mathrm{R}$ & $\mathrm{F}$ & $\mathrm{F}$ & $\mathrm{F}$ \\
\hline Reticulofenestra cf. daviesii & & & & & $\mathrm{F}$ & $\mathrm{R}$ \\
\hline Reticulofenestra umbilica & $\mathrm{F}$ & $\mathrm{F}$ & $\mathrm{C}$ & $\mathrm{C}$ & $\mathrm{C}$ & A \\
\hline Sphenolithus cf. furcatolithoides & & $\mathrm{R}$ & $\mathrm{F}$ & $\mathrm{C}$ & $\mathrm{R}$ & $\mathrm{F}$ \\
\hline Sphenolithus moriformis & $\mathrm{F}$ & $\mathrm{F}$ & $\mathrm{R}$ & $\mathrm{F}$ & $\mathrm{F}$ & $\mathrm{R}$ \\
\hline Sphenolithus predistentus? & & $\mathrm{R}$ & & & & $\mathrm{R}$ \\
\hline Sphenolithus spiniger & & & & & & $\mathrm{R}$ \\
\hline Thoracosphaera spp. & $\mathrm{R}$ & $\mathrm{R}$ & $\mathrm{R}$ & $\mathrm{F}$ & $\mathrm{R}$ & $\mathrm{C}$ \\
\hline Zygrablithus bijugatus & $\mathrm{C}$ & $\mathrm{F}$ & $\mathrm{C}$ & $\mathrm{F}$ & $\mathrm{F}$ & $\mathrm{C}$ \\
\hline
\end{tabular}

$\mathrm{VA}=$ Very Abundant, $\mathrm{A}=$ abundant, $\mathrm{C}=$ Common, $\mathrm{F}=$ Few, $\mathrm{R}=$ Rare $, \mathrm{G}=\mathrm{Good}, \mathrm{M}=$ Moderate, $\mathrm{P}=$ Poor 


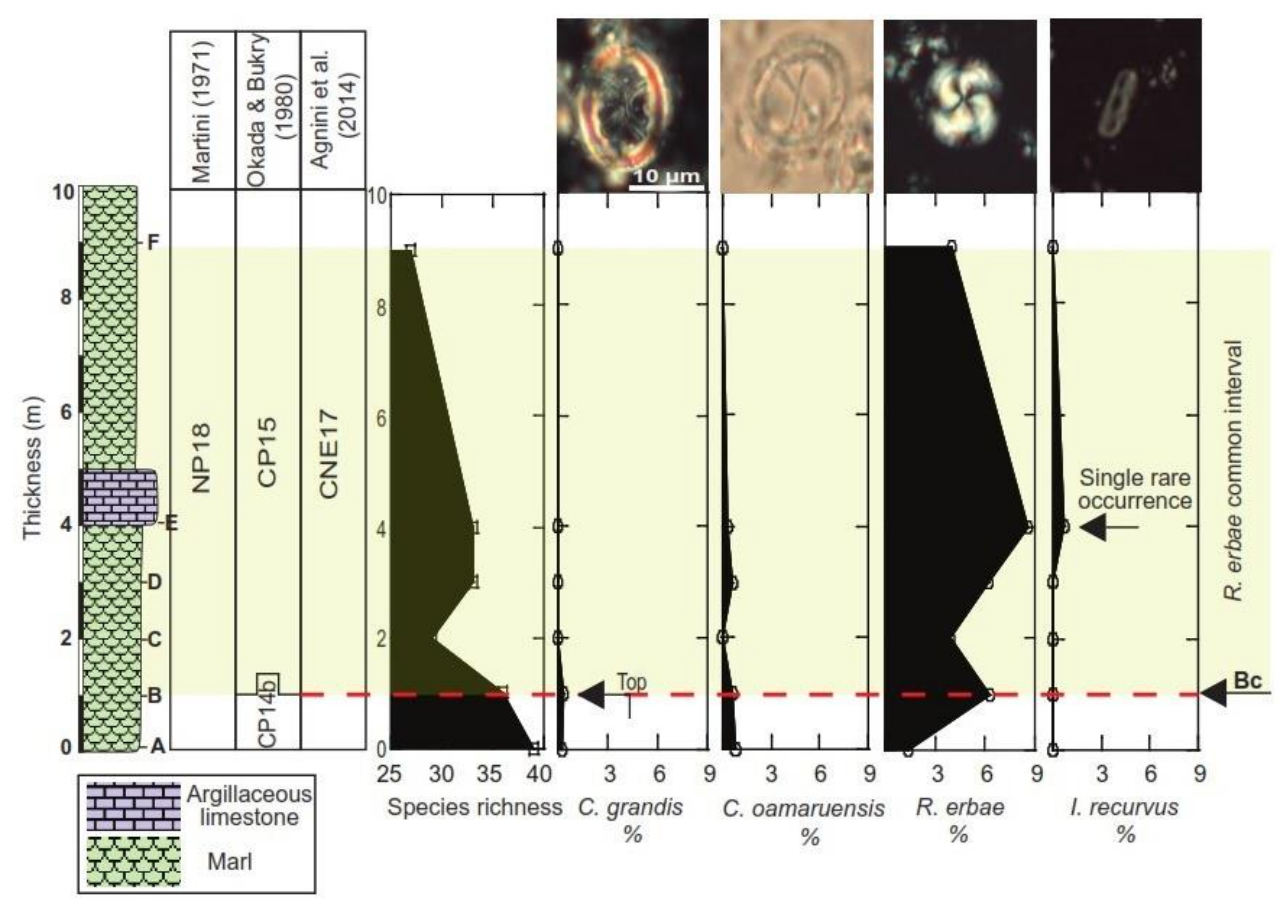

Figure 3. Major calcareous nannofossil percentage (\%) events detected in this study within the upper Eocene Rashrashiyah Formation in northern Saudi Arabia compared to the global zonation of Martini (1971), Okada and Bukry (1980) and Agnini et al. (2014). The dashed red line represents the bioevents of $C$. grandis, and the Base common $(B c)$ of $R$. erbae

\section{Discussion}

\section{Upper Eocene nannofossil bioevents in northern Saudi Arabia}

Calcareous nannofossils are an excellent group of microfossils for biostratigraphic and global correlation studies (Agnini et al., 2014; Raffi et al., 2016). This is due to their high rates of speciation since their first appearance in the late Triassic (Gardin et al., 2012). In the late Eocene, calcareous nannofossils have shown profound provincialism (Aubry, 1992; Wei and Wise, 1990) as a response to the expansion of the Antarctica ice sheet (Miller et al., 1991; Zachos et al., 2001). This provincialism caused some upper Eocene nannofossil biomarkers to be unreliable for biostratigraphy and the global correlation between low- and high-latitude regions (Agnini et al., 2011; Wei and Wise, 1989, 1990; Fioroni et al., 2012). This has greatly affected the recognition of some Martini (1971) and Okada and Bukry (1980) zones throughout global localities (Perch-Nielsen, 1985), hence, no formal identification of Global Stratotype Section Point (GSSP) has been found (Agnini et al., 2011). Our section spans Zone NP18 of Martini (1971) and is correlated with the middle and upper part of the upper Eocene Wadi Esh-Shallalah Formation section (Farouk et al., 2015) in Jordan, $26 \mathrm{Km}$ NW of the Rashrashiyah Formation section studied in this report. Here we discuss the occurrence of the biomarker species observed in northern Saudi Arabia and their possible correlation regionally and globally.

\section{Top of Chiasmolithus grandis}

The extinct Chiasmolithus genus was found to occupy high-latitude regions between the middle Eocene-Oligocene timeframe (Wei and Wise, 1989). The top of $C$. grandis was detected in Sample B slightly above the base of the section (Fig. 4) and primarily 
points out to the CP14b/CP15 boundary of Okada and Bukry (1980) zonation. This bioevent lies within Zone NP18 of Martini (1971) and Zone CNE17 of Agnini et al. (2014) due to the presence of rare-few $C$. oamaruensis and the Base common (Bc) of $R$. erbae (Fig. 4) just above the base of the section (Fig. 4). Chiasmolithus grandis and $C$. oamaruensis were found to overlap within the studied portion of the Rashrashiyah Formation (Figs. 3 and 4). This behavior in overlapping is documented in Egypt (Strougo et al., 2013) and in Jordan (Farouk et al., 2015), Italian Alano section (Agnini et al., 2011), and the Ocean Drilling Program (ODP) in the Indian Ocean (Fioroni et al., 2015). Chiasmolithus grandis exhibited a sharp top event, whereas $C$. oamaruensis was found to be within $<1 \%$ of the total assemblage with sporadic occurrence toward up section (Fig. 3) similar to local and regional observations (Farouk et al., 2015; Strougo et al., 2013). Additionally, the top of $C$. grandis was also observed at the same stratigraphic level of the Bc of R. erbae (Fig. 4).

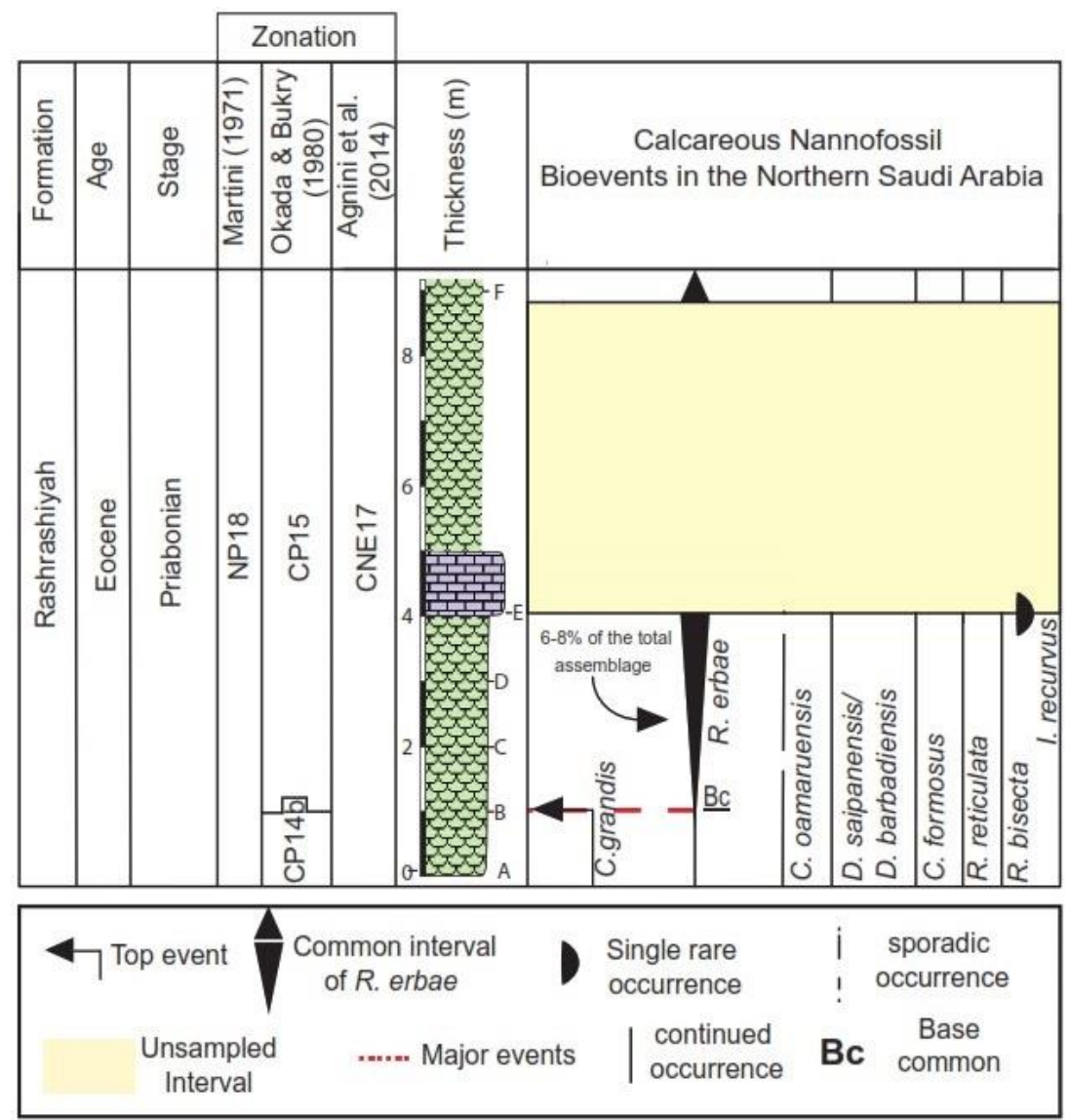

Figure 4. Calcareous nannofossils bioevents of the studied portion of the Rashrashyiah Formation from northern Saudi Arabia aligned with Eocene nannoplanktonic zonation

\section{Base common $(B c)$ of Reticulofenestra erbae}

Fornaciari et al. (2010) described two new significant middle-late Eocene biomarkers species, $R$. erbae and $R$. isabellae, that Agnini et al. (2014) utilized in their recent Paleogene zonation. Reticulofenestra erbae is differentiated from $R$. isabellae by size in which the latter is $\geq 12 \mu \mathrm{m}$ (Fornaciari et al., 2010). Reticulofenestra erbae showed few abundances in sample A (Table 1), but substantially increased reached to 6-8\% of the 
total assemblage, between samples B-F, within Zone NP18 (Martini, 1971) and base of Zone CP15 (Okada and Bukry 1980) (Fig. 4). The increase of R. erbae started at the level of sample B and continued upward throughout the rest of the studied section (Figs. 3 and 4 ), hence, we could not observe the Top common (Tc). The Bc of $R$. erbae coincides with the top of C. grandis (Fig. 4) in our section. Agnini et al. (2014) have shown that the top of $C$. grandis lies slightly above the Bc of $R$. erbae in the North Atlantic (ODP Site 1052). This earlier top event of $C$. grandis in our study (Fig. 4) could be related to sampling resolution or diachrony in $C$. grandis (Agnini et al., 2014; Fioroni et al., 2015). Overall, the distribution pattern of $R$. erbae with the recognizable increase abundance greatly validates the $\mathrm{Bc} R$. erbae usefulness in northern Saudi Arabia.

Recent integrated biostratigraphic studies from local and regional sections in Jordan and Egypt have shown the presence of both $R$. erbae and $R$. isabellae together within Martini (1971) Zones NP17-18 (Farouk et al., 2015; Strougo et al., 2013). However, the two biomarker species have been observed well-spaced in time, both in deep-sea cores and land-based section (Agnini et al., 2014; Fornaciari et al., 2010). In this study, the overlapping of both species has not been detected, furthermore, even their base events did not coincide together herein. Reticulofenestra isabellae appeared later in Zones CNE19 (Agnini et al., 2014) and NP19/20 of Martini (1971). Morphometric measurements of random medium to large placolith ( $R$. erbae and $R$. reticulata) species throughout the section were carried out to observe the size pattern and scrutinize the section for the presence of $R$. isabellae (Fig. 5). Within the designated study area; which is only $26 \mathrm{~km}$ SE of the Jordanian Qa' Faydat ad Dahikiya (Farouk et al., 2015), only R. erbae is found, following the description criteria of Fornaciari et al. (2010), ranging in size between 8-10 $\mu \mathrm{m}$ (Fig. 5), while the presence of $R$. isabellae was not recorded. Therefore, the presence of $R$. isabellae in previous local studies is possibly misidentified and/or miscalibrated in size with large specimens of $R$. erbae.

\section{The single isolated occurrence of Isthmolithus recurvus}

The base of I. recurvus is a bioevent utilized in the zonations of Martini (1971) and Okada and Bukry (1980) for the late Eocene. Biogeographic studies of this taxon have shown its preference and inclination toward cool-water and high-latitude regions (Wei and Wise, 1989, 1990); while it is rare with discontinuous occurrence in low-latitudes areas (Agnini et al., 2014; Farouk et al., 2015; Strougo et al., 2013; Wei and Wise, 1990; Fioroni et al., 2015) and our section in northern Saudi Arabia. Isthmolithus recurvus has first appeared in sample F with only 2 species $(0.6 \%$; Fig. 3). No I. recurvus was detected at sample E (Fig. 4). This taxon showed two distinct bioevents in the Mediterranean region (Fornaciari et al., 2010). The first appearance is short, more isolated occurrence termed 'spike' which probably here lies within Zones NP18 (Martini, 1971), CP15 (Okada and Bukry, 1980) and CNE17 (Agnini et al., 2014) (Fig. 4), whereas the second bioevent seems to be the lowest common occurrence (Fornaciari et al., 2010) that confidently used for base Zone NP19 of Martini (1971).

The earlier occurrence "spike" has also been observed in deep-sea cores Agnini et al., 2014; Fornaciari et al., 2010; Fioroni et al., 2015; Villa et al., 2008) which reflects a more consistent occurrence outside the Mediterranean region. The single isolated occurrence of $I$. recurvus observed in our section was found to coincide with the maximum increase in R. erbae (Figs. 3 and 4). Owing to the unsampled interval of $\sim 5 \mathrm{~m}$ (Fig. 4), that was hindered to collect in the field due to mineralized (dolomitized rocks), concerns about the usefulness/correlation of this short occurrence remains unclear in northern Saudi Arabia 
despite the fact of producibility of the bioevent globally (Agnini et al., 2014; Fornaciari et al., 2010). Besides, sample $\mathrm{E}$ the from the top section, where species richness declined down to 27 species and preservation became moderate to poor, shows no I. recurvus or $R$. isabellae, indicating that the top of the studied section still lies within Zone NP18 (Martini, 1971) or Zone CNE17 (Agnini et al., 2014).

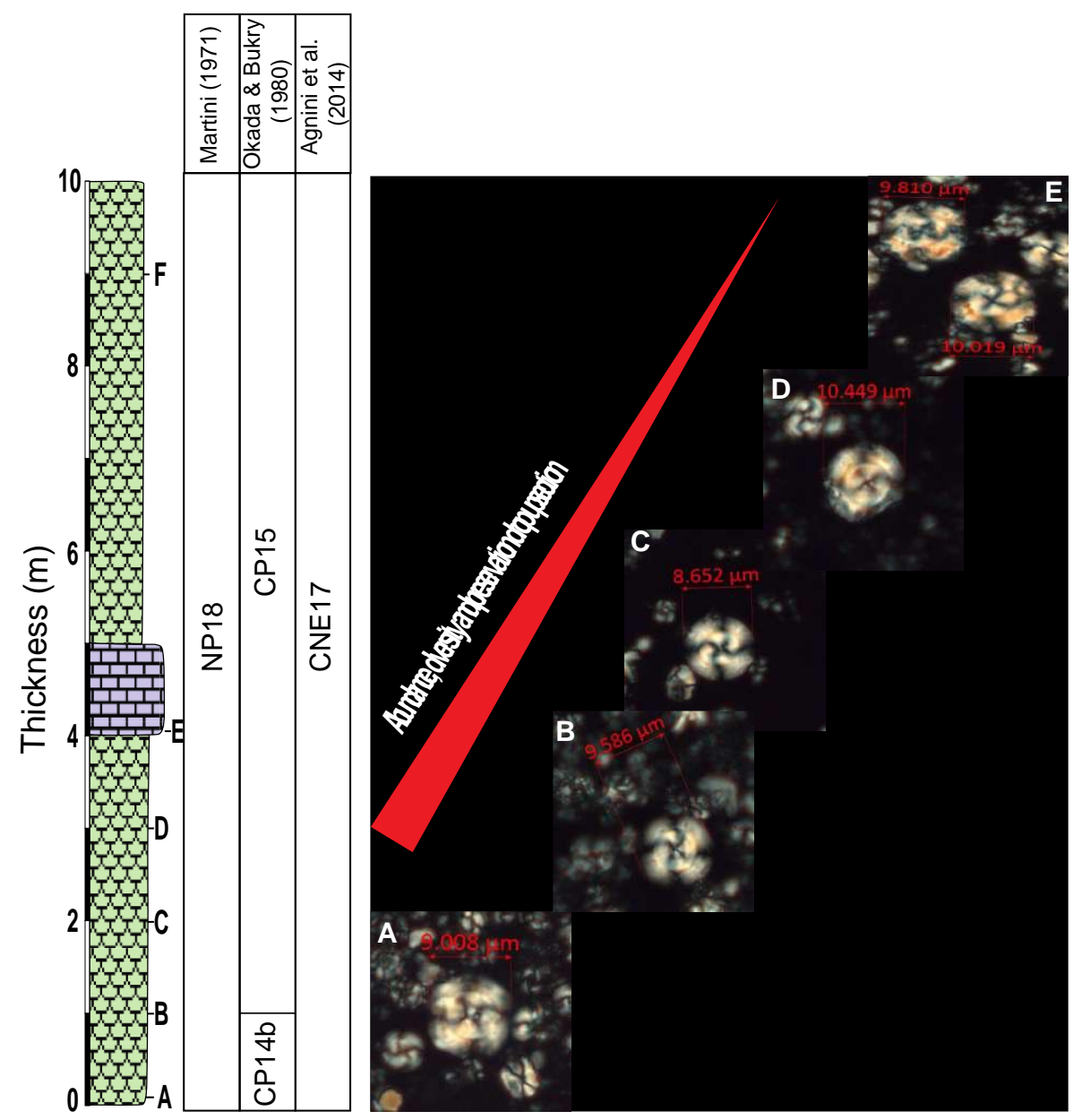

Figure 5. Morphometric measurements of the largest Reticulofenestra erbae/R. reticulata within CNE 17 Zone, from the upper part of the Rashrashiayh Formation section in northern Saudi Arabia

Side views of Isthmolithus recurvus from Egyptian and Jordanian sampled sections appeared near the base of Zone NP18 with rare occurrences (Farouk et al., 2015; Strougo et al., 2013). The calcareous nannofossil assemblage of the Rashrashiyah Formation in northern Saudi Arabia shows no side views of I. recurvus, only overgrown planer view of $I$. recurvus specimens were only observed in sample E (Plate 1).

\section{The decline in diversity and preservation: tectonism, eustacy, and regional correlation}

It is evident that a major drop in species richness accompanied by the deterioration in preservation took place toward the top of the studied section (Fig. 5). This drop in the species richness at the top of the Rashrashiyah Formation is a quite similar case reported 
from Zones NP17-18 of the Wadi Esh-Shallalah Formation section across the borders in Jordan. Below the top of the studied Saudi section, it seems that a tremendous amount of nannofossil fragmentation increased (Plate 2). During the late Eocene, the northern part of the Arabian Peninsula, as part of the Alpine Orogeny and the Syrian Arc Belt (Bosworth et al., 1999; Guiraud and Bosworth, 1999), witnessed severe compressional events with crustal shortening within the NW-SE direction. These compressional events produced significant topographical changes causing different depositional and erosional processes during the rest of the Eocene and later Paleogene and Neogene systems. Moreover, the presence of shallow-marine planktic foraminifera in the earliest Oligocene of the correlatable Jordanian section (Farouk et al., 2015) suggests that the basin, including our formation, was subjected to large changes in sea level.
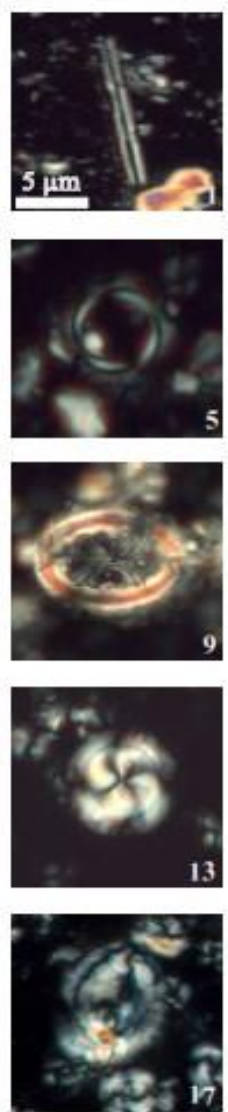
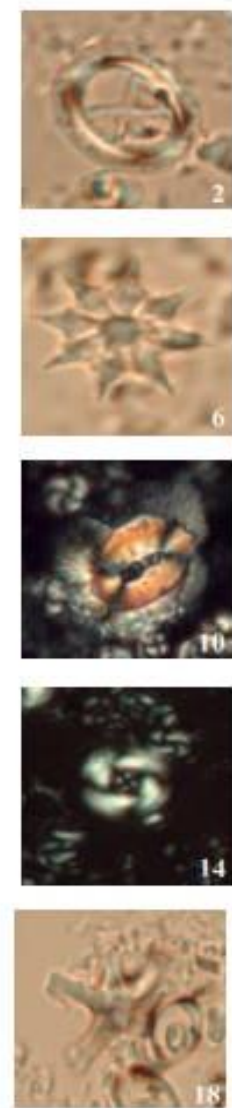
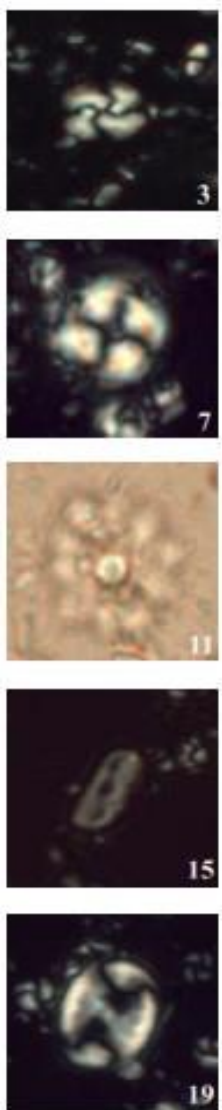
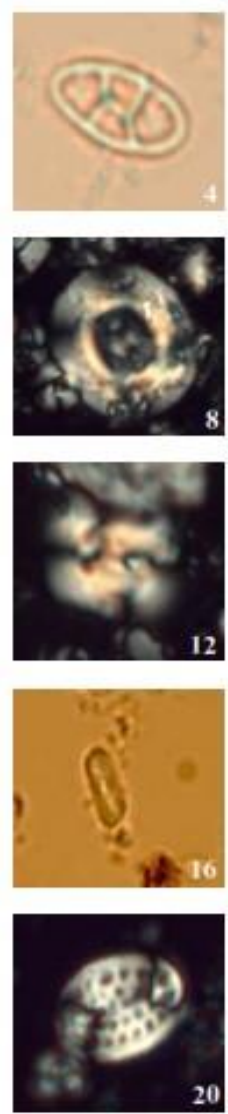

Plate 1. Polarized and plain-light micrographs of calcareous nannofossil taxa identified in AlRashrashiyah Formation in northern Saudi Arabia. 1. Blackites spinosus, sample A. 2.

Chiasmolithus oamaruensis, sample A, 3. Cyclicargolithus floridanus, sample A, 4.

Neococcolithes dubius, sample A, 5. Cyclococcolithina protoannula, sample A, 6. Discoaster saipanensis, sample B, 7. Coccolithus formosus, sample A, 8. Reticulofenestra umbilicus, sample D, 9. Chiasmolithus grandis, sample A, 10. Coccolithus eopelagicus, sample C, 11. Discoaster barbadiensis, sample E, 12. Reticulofenestra bisecta, sample A, 13. Reticulofenestra erbae, sample B, 14. Reticulofenestra reticulata, sample C, 15-16. Isthmolithus recurvus, Sample E, 17.

Helicosphaera compacta, sample A, 18. Discoaster tanii, sample B, 19. Pontosphaera exilis, sample A, 20. Pontosphaera multipora, sample B. (magnification of $1000 \times$, scale bar 5 microns for all images as in $A$ ) 

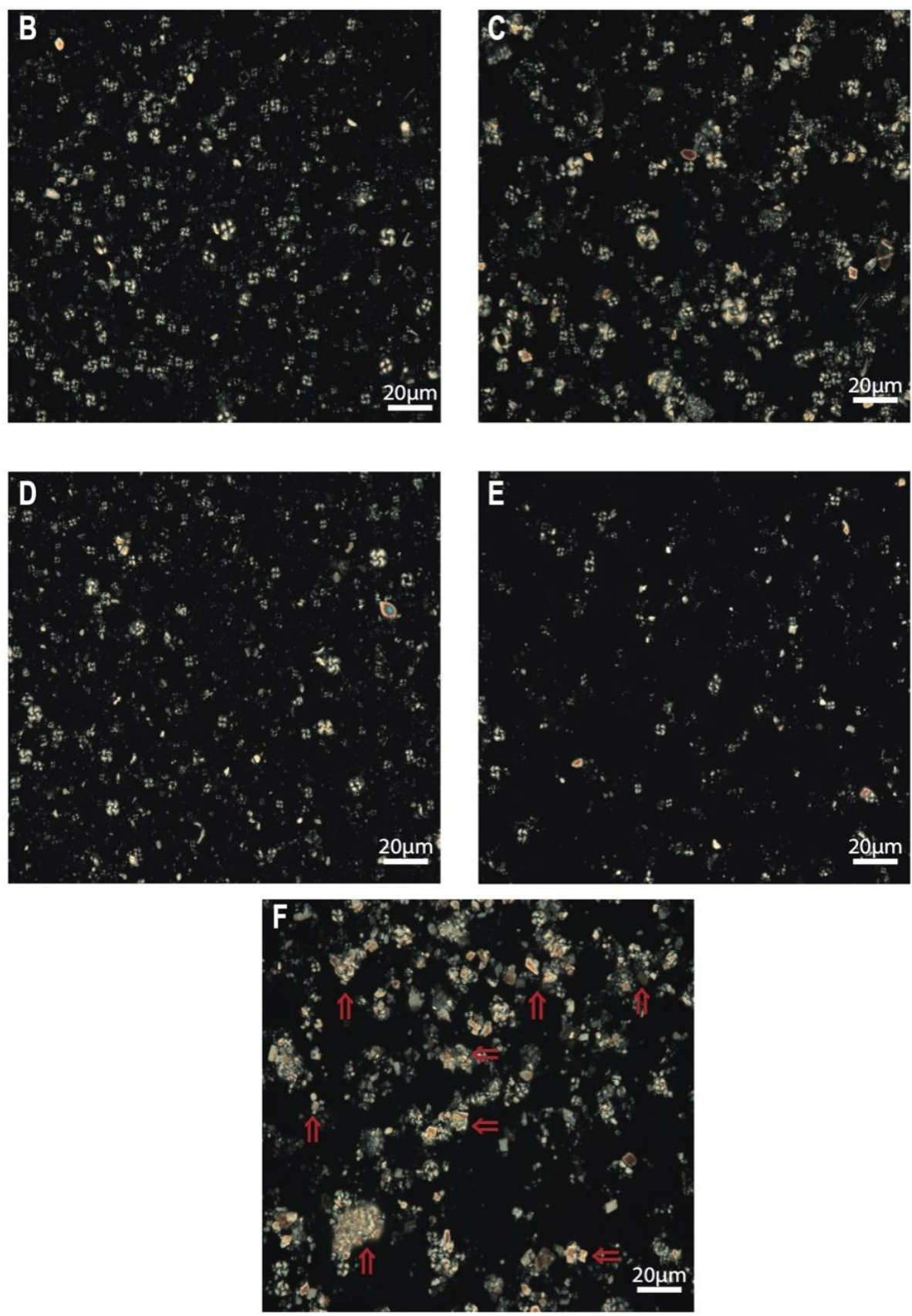

Plate 2. Polarized views (magnification of $1000 \times$, scale bar 20 microns) showing the degree of fragmentations (red arrows) toward up section from Samples B-F

\section{Conclusions}

The studied part of the Rashrashiyah Formation is the only surface section to reveal a high diversity of well-preserved calcareous nannofossils at its base but deteriorate toward the top of the section. Three calcareous nannofossil zones of global zonations were recognized and all indicate an early Priabonian age based on the rare and sporadic occurrence of $C$. oamaruensis of Zone NP18. The Base common $(\mathrm{Bc})$ of $R$. erbae is documented here with a common increase from $6-8 \%$ of the total assemblage and the 
section lies within Zone CNE17. The sharp top event of $C$. grandis was detected, at the same level of Bc of $R$. erbae, and subdivided CP14b/CP15 zones. A single and more isolated occurrence of $I$. recurvus was observed parallel with the maximum increase of $R$. erbae. This isolated single occurrence, due to sampling resolution, cannot be compared/correlated with those sections in the Mediterranean and deep-sea cores. Reticulofenestra isabellae, a biomarker species found in accordance with the Lowest Common Occurrence (LCO) of I. recurvus, has not been observed, hence, the Rashrashiyah Formation section tentatively lies within Zone NP18/CNE17. Although the side view of $I$. recurvus specimens was recorded in Egyptian and Jordanian sections to originate at the base of NP18, only planner view specimens were observed in northern Saudi Arabia. The investigated calcareous nannofossil record at the Rashrashiyah Formation section is partially correlatable with the adjacent Jordanian Wadi EshShallalah Formation section in Qa' Faydat Ad Dahikiya. The decline in species richness toward the top of our studied section is also comparable with Wadi Esh-Shallalah Formation, which reflects major tectonic activity originated during the late Eocene. The studied stratigraphic interval from the Rashrashiyah Formation, so far, is the only Eocene section to reveal calcareous nannofossils, recorded for the first time in Saudi Arabia. Hence, this report represents part of a larger ongoing investigation attempting to code the Paleogene sediments in Saudi Arabia with the global nannoplankton and foraminiferal zonation. The ongoing research plans to intergrade benthic and planktic foraminifera for more robust age determination and biostratigraphical correlation with local and regional sections. Reconstructions of Paleogene climate change and global sea-level via integrated stable isotope signature are needed from expanded outcrop sections in northern Saudi Arabia.

Acknowledgments. This project was funded by the Deanship of Scientific Research (DSR), King Abdulaziz University, Jeddah, under grant No. (D-288-150-1440). The authors, therefore, gratefully acknowledge the DSR technical and financial support. We would like to thank Prof. Giuliani Villa for her constructive comments and suggestions that improved the initial manuscript. We thank the Department of Paleontology of the Saudi Geological Survey (SGS) and the leadership of SGS represented by Saleh AlSefry, Nasser Aljahdali, and Wadee Kashghari for supporting fieldwork, permission to use SGS labs and equipment for this work. The authors would like to thank the editor and anonymous reviewers for their constructive comments and suggestions that substantially improved the manuscript.

\section{REFERENCES}

[1] Agnini, C., Fornaciari, E., Giusberti, L., Grandesso, P., Lanci, L., Luciani, V., Muttoni, G., Pälike, H., Rio, D., Spofforth, D. J. (2011): Integrated biomagnetostratigraphy of the Alano Section (Ne Italy): a proposal for defining the Middle-Late Eocene boundary. - GSA Bulletin 123(5-6): 841-872.

[2] Agnini, C., Fornaciari, E., Raffi, I., Catanzariti, R., Pälike, H., Backman, J., Rio, D. (2014): Biozonation and biochronology of Paleogene calcareous nannofossils from low and middle latitudes. - Newsletters on Stratigraphy 47(2): 131-181.

[3] Al-Rawi, M. M. (2014): Petroleum systems in Jordan. - GEO ExPro 11(1).

[4] Aubry, M. (1992): Late Paleogene Calcareous Nannoplankton Evolution: A Tale of Climatic Deterioration. - In: Prothero, D. R., Berggren, W. A. (eds.) Eocene-Oligocene Climatic and Biotic Evolution. Princeton University Press, Princeton, NJ.

[5] Bahrawi, J. A., Elhag, M. (2016): Simulation of sea level rise and its impacts on the western coastal area of Saudi Arabia. - Indian Journal of Geo-Marine Sciences 45(1): 54-61. 
[6] Bahrawi, J., Elhag, M. (2019): Consideration of seasonal variations of water radiometric indices for the estimation of soil moisture content in arid environment in Saudi Arabia. Applied Ecology and Environmental Research 17(1): 285-303.

[7] Bender, F. (1968): Geologie Von Jordanien. - Beitraege Zur Regionalen Geologie. Region. Geol. d. Erde 7.

[8] Berggren, W. A., Kent, D. V., Swisher Iii, C. C., Aubry, M.-P. (1995): A Revised Cenozoic Geochronology and Chronostratigraphy. - In: Berggren, W. A. et al. (eds.) Geochronology, Time Scales and Global Stratigraphic Correlation. SEPM Society for Sedimentary Geology, Tulsa, OK.

[9] Bosworth, W., Guiraud, R., Kessler, L. (1999): Late Cretaceous (Ca. 84 Ma) compressive deformation of the stable platform of Northeast Africa (Egypt): far-field stress effects of the "Santonian Event" and origin of the Syrian Arc Deformation Belt. - Geology 27(7): 633636.

[10] Bown, P. R., Dunkley Jones, T. (2012): Calcareous nannofossils from the paleogene Equatorial Pacific (IODP Expedition 320 Sites U1331-1334). - Journal of Nannoplankton Research 32(2): 3-51.

[11] Bown, P. R., Burnett, J. A., Gallagher, L. T. (1991): Critical events in the evolutionary history of calcareous nannoplankton. - Historical Biology 5(2-4): 279-290.

[12] Bown, P. R., Lees, J. A., Young, J. R. (2004): Calcareous Nannoplankton Evolution and Diversity through Time. - In: Thierstein, H. R., Young, J. R. (eds.) Coccolithophores. Springer, Berlin, pp. 481-508.

[13] Cotton, L. J., Zakrevskaya, E. Y., Van Der Boon, A., Asatryan, G., Hayrapetyan, F., Israyelyan, A., Krijgsman, W., Less, G., Monechi, S., Papazzoni, C. A. (2017): Integrated stratigraphy of the Priabonian (Upper Eocene) Urtsadzor Section, Armenia. - Newsletters on Stratigraphy 50(3): 269-295.

[14] Elhag, M., Bahrawi, J. A. (2019): Sedimentation mapping in shallow shoreline of arid environments using active remote sensing data. - Natural Hazards 99(2): 879-894.

[15] Elhag, M., Galal, H. K., Alsubaie, H. (2017): Understanding of morphometric features for adequate water resource management in arid environments. - Geoscientific Instrumentation, Methods and Data Systems 6(2): 293.

[16] Farouk, S., Faris, M., Ahmad, F., Powell, J. H. (2015): New microplanktonic biostratigraphy and depositional sequences across the Middle-Late Eocene and Oligocene boundaries in Eastern Jordan. - GeoArabia 20(3): 145-172.

[17] Fioroni, C., Villa, G., Persico, D., Wise, S. W., Pea, L. (2012): Revised Middle Eocene-Upper Oligocene calcareous nannofossil biozonation for the Southern Ocean. - Revue de micropaléontologie 55(2): 53-70.

[18] Fioroni, C., Villa, G., Persico, D., Jovane, L. (2015): Middle Eocene-Lower Oligocene calcareous nannofossil biostratigraphy and paleoceanographic implications from site 711 (Equatorial Indian Ocean). - Marine Micropaleontology 118: 50-62.

[19] Fornaciari, E., Agnini, C., Catanzariti, R., Rio, D., Bolla, E. M., Valvasoni, E. (2010): Midlatitude calcareous nannofossil biostratigraphy and biochronology across the Middle to Late Eocene transition. - Stratigraphy 7(4): 229.

[20] Gardin, S., Galbrun, B., Thibault, N., Coccioni, R., Silva, I. P. (2012): Biomagnetochronology for the Upper Campanian-Maastrichtian from the Gubbio Area, Italy: new results from the Contessa Highway and Bottaccione sections. - Newsletters on Stratigraphy 45(1): 75-103.

[21] Guiraud, R., Bosworth, W. (1999): Phanerozoic geodynamic evolution of northeastern Africa and the northwestern Arabian Platform. - Tectonophysics 315(1-4): 73-104.

[22] Guiraud, R., Issawi, B., Bosworth, W. (2001): Phanerozoic history of Egypt and surrounding areas. - Peri-Tethys Memoir 6: 469-509.

[23] Halawani, M. (2001): Stratigraphic column for the Phanerozoic rocks of Saudi Arabia. A compilation and synthesis with comments. - Saudi Geological Survey Technical Reports, Kingdom of Saudi Arabia SGS-TR-2001-3 2001: 4. 
[24] Krasheninnikov, V. A., Golovin, D. I., Mouravyov, V. I., Helou, R. (1996): The Paleogene of Syria--Stratigraphy, Lithology, Geochronology. - In: Krasheninnikov, V. A., et al. (eds.) Geologisches Jahrbuch, Reihe B, Regionale Geologie Ausland. Schweizerbart, Stuttgart.

[25] Martini, E. (1971): Standard Tertiary and Quaternary calcareous nannoplankton zonation. Proc. II Planktonic Conference, Roma, 1970. Tecnoscienza, Roma.

[26] Meissner, C. R., Griffin, M. B. Jr., Riddler, G. P., Marcel Van Eck, Aspinall, N. C., Farasani, A. M., Dini, S. M. (1990): Preliminary Geologic Map of the Thaniyat Turayf Quadrangle, Sheet 29c, Kingdom of Saudi Arabia - Department of the Interior, US Geological Survey, Washington, DC.

[27] Miller, K. G., Wright, J. D., Fairbanks, R. G. (1991): Unlocking the ice house: OligoceneMiocene oxygen isotopes, eustasy, and margin erosion. - Journal of Geophysical Research: Solid Earth 96(B4): 6829-6848.

[28] Miller, K. G., Browning, J. V., Aubry, M.-P., Wade, B. S., Katz, M. E., Kulpecz, A. A., Wright, J. D. (2008): Eocene-Oligocene global climate and sea-level changes: St. Stephens quarry, Alabama. - GSA Bulletin 120(1-2): 34-53.

[29] Mustafa, H., Zalmout, I. (2002): Elasmobranchs from the Late Eocene Wadi Esh-Shallala Formation Ofqa' faydat Ad Dahikiya, East Jordan. - Tertiary Research 21(1/4): 77-94.

[30] Okada, H., Bukry, D. (1980): Supplementary modification and introduction of code numbers to the low-latitude coccolith biostratigraphy (Bukry 1973; 1975). - Mar. Micropaleontol. 5: 321-325.

[31] Pagani, M., Zachos, J. C., Freeman, K. H., Tipple, B., Bohaty, S. (2005): Marked decline in atmospheric carbon dioxide concentrations during the Paleogene. - Science 309(5734): 600603.

[32] Pälike, H., Norris, R. D., Herrle, J. O., Wilson, P. A., Coxall, H. K., Lear, C. H., Shackleton, N. J., Tripati, A. K., Wade, B. S. (2006): The heartbeat of the Oligocene climate system. Science 314(5807): 1894-1898.

[33] Perch-Nielsen, K. (1985): Cenozoic Calcareous Nannofossils. - In: Bolli, H. M., Saunders, J. B., Perch-Nielsen, K. (eds.) Plankton Stratigraphy. Cambridge University Press, Cambridge.

[34] Powers, R., Ramirez, L., Redmond, C., Elberg, E. (1966): Geology of the Arabian Peninsula. - Geological Survey Professional Paper 560: 1-147.

[35] Raffi, I., Agnini, C., Backman, J., Catanzariti, R., Pälike, H. (2016): A cenozoic calcareous nannofossil biozonation from low and middle latitudes: a synthesis. - Journal of Nannoplankton Research 36(2): 121-132.

[36] Strougo, A., Faris, M., Abul-Nasr, R. A., Gingerich, P. D., Haggag, M. A. (2013): Planktonic foraminifera and calcareous nannofossil biostratigraphy through the Middle to Late Eocene transition at Wadi Hitan, Fayum Province, Egypt. - Journal of Paleontology 32(8).

[37] TSCreator visualization of enhanced Geologic Time Scale 2016 database (Version 7.4; 2020) James Ogg (database coordinator) https://engineering.purdue.edu/Stratigraphy/tscreator.

[38] Villa, G., Fioroni, C., Pea, L., Bohaty, S., Persico, D. (2008): Middle Eocene-Late Oligocene climate variability: calcareous nannofossil response at Kerguelen Plateau, site 748. - Marine Micropaleontology 69(2): 173-192.

[39] Wallace, C. A., Dini, S. M., Al-Farasani, A. N. (1994): Geological map of part of the Turayf Quadrangle, Sheet 31C, and An Nabk Quadrangle, Sheet 31B, Kingdom of Saudi Arabia. Ministry of Petroleum and Mineral resources, Saudi Geological Survey: Geoscience Map Series GM-125C.

[40] Wei, W., Wise, S. W. Jr (1989): Paleogene calcareous nannofossil magnetobiochronology: results from South Atlantic DSDP site 516. - Marine Micropaleontology 14(1-3): 119-152.

[41] Wei, W., Wise, S. W. Jr (1990): Biogeographic gradients of Middle Eocene-Oligocene Calcareous nannoplankton in the South Atlantic Ocean. - Palaeogeography, Palaeoclimatology, Palaeoecology 79(1-2): 29-61.

[42] Zachos, J., Pagani, M., Sloan, L., Thomas, E., Billups, K. (2001): Trends, rhythms, and aberrations in global climate 65 Ma to Present. - Science 292(5517): 686-693. 
[43] Zalmout, I. S., Mustafa, H. A., Gingerich, P. D. (2000): Priabonian Basilosaurus isis (Cetacea) from the Wadi Esh-Shallala Formation: first marine mammal from the Eocene of Jordan. - Journal of Vertebrate Paleontology 20(1): 201-204.

\section{APPENDIX}

Appendix A: Raw range chart and percentage counts.

\begin{tabular}{|c|c|c|c|c|c|c|}
\hline Sample & $\mathrm{F}$ & $\mathrm{E}$ & $\mathrm{D}$ & $\mathrm{C}$ & $\mathrm{B}$ & A \\
\hline Height $(\mathrm{m})$ & 9 & 4 & 3 & 2 & 1 & 0 \\
\hline Martini (1971) & \multicolumn{6}{|c|}{ NP18 } \\
\hline Okada and Bukry (1980) & \multicolumn{4}{|c|}{ CP15 } & \multicolumn{2}{|c|}{$\mathrm{CP} 14 \mathrm{~b}$} \\
\hline Agnini et al. (2014) & \multicolumn{6}{|c|}{ CNE17 } \\
\hline Diversity & 27 & 33 & 33 & 29 & 36 & 39 \\
\hline Preservation & $\mathrm{P}$ & M-P & $\mathrm{M}$ & $\mathrm{G}$ & M-G & $\mathrm{G}$ \\
\hline Group Abundance & $\mathrm{C}$ & $\mathrm{A}$ & VA & VA & VA & VA \\
\hline Blackites cf. morionum & & & & & $\mathrm{R}$ & $\mathrm{C}$ \\
\hline Blackites spinosus & $\mathrm{F}$ & $\mathrm{C}$ & $\mathrm{A}$ & $\mathrm{F}$ & $\mathrm{F}$ & $\mathrm{F}$ \\
\hline Braarudosphaera bigelowii & $\mathrm{R}$ & $\mathrm{R}$ & & & & \\
\hline Chiasmolithus grandis & & & & & $\mathbf{R}$ & $\mathrm{R}$ \\
\hline Chiasmolithus oamaruensis & & $\mathrm{R}$ & $\mathrm{R}$ & & $\mathrm{R}$ & $\mathbf{F}$ \\
\hline Clausicoccus subdistichtus & $\mathrm{F}$ & $\mathrm{C}$ & $\mathrm{C}$ & $\mathrm{C}$ & A & $\mathrm{R}$ \\
\hline Coccolithus eopelagicus & $\mathrm{C}$ & $\mathrm{R}$ & $\mathrm{R}$ & $\mathrm{R}$ & $\mathrm{R}$ & $\mathrm{A}$ \\
\hline Coccolithus pelagicus & $\mathrm{A}$ & A & A & A & A & $\mathrm{F}$ \\
\hline Cruciplacolithus cruciformis & & $\mathrm{R}$ & $\mathrm{R}$ & & $\mathrm{F}$ & $\mathrm{A}$ \\
\hline Cyclicargolithus floridanus $<5$ & $\mathrm{~A}$ & A & A & A & $\mathrm{A}$ & $\mathrm{A}$ \\
\hline Cyclicargolithus floridanus & $\mathrm{A}$ & $\mathrm{A}$ & A & A & $\mathrm{A}$ & $\mathrm{F}$ \\
\hline Discoaster barbadiensis & $\mathrm{F}$ & $\mathrm{F}$ & $\mathrm{F}$ & $\mathrm{F}$ & $\mathrm{F}$ & $\mathrm{A}$ \\
\hline Discoaster saipanensis & $\mathrm{F}$ & $\mathrm{F}$ & A & $\mathrm{C}$ & $\mathrm{C}$ & $\mathrm{R}$ \\
\hline Discoaster tanii & $\mathrm{R}$ & $\mathrm{R}$ & $\mathrm{R}$ & & & $\mathrm{R}$ \\
\hline Coccolithus formosus & $\mathrm{C}$ & $\mathrm{C}$ & $\mathrm{R}$ & $\mathrm{C}$ & $\mathrm{C}$ & $\mathrm{C}$ \\
\hline Helicosphaera bramlettii & $\mathrm{C}$ & $\mathrm{C}$ & $\mathrm{C}$ & $\mathrm{C}$ & $\mathrm{R}$ & \\
\hline Helicosphaera compacta & $\mathrm{F}$ & $\mathrm{R}$ & $\mathrm{F}$ & $\mathrm{R}$ & $\mathrm{R}$ & $\mathrm{R}$ \\
\hline Helicosphaera reticulata & & $\mathrm{R}$ & $\mathrm{R}$ & $\mathrm{F}$ & & \\
\hline Helicosphaera wilcoxii & & $\mathrm{R}$ & $\mathrm{F}$ & & & \\
\hline Hughesius tasmaniae & & & & & & $\mathrm{C}$ \\
\hline Isthmolithus recurvus & & $\mathbf{R}$ & & & & \\
\hline Lanternithus minutus & $\mathrm{C}$ & $\mathrm{F}$ & $\mathrm{F}$ & $\mathrm{C}$ & $\mathrm{F}$ & $\mathrm{F}$ \\
\hline Neococcolithes dubius & & & $\mathrm{F}$ & $\mathrm{R}$ & $\mathrm{R}$ & $\mathrm{F}$ \\
\hline Pedinocyclus gibbsiae & $\mathrm{F}$ & $\mathrm{F}$ & $\mathrm{C}$ & $\mathrm{F}$ & $\mathrm{C}$ & \\
\hline Pontosphaera exilis & & & & & $\mathrm{F}$ & $\mathrm{F}$ \\
\hline Pontosphaera panarium & & & & $\mathrm{R}$ & $\mathrm{R}$ & $\mathrm{R}$ \\
\hline Pontosphaera multipora & & $\mathrm{R}$ & $\mathrm{R}$ & $\mathrm{R}$ & $\mathrm{F}$ & $\mathrm{C}$ \\
\hline Reticulofenestra bisecta & $\mathrm{A}$ & $\mathrm{R}$ & $\mathrm{F}$ & & $\mathrm{C}$ & $\mathrm{F}$ \\
\hline Reticulofenestra daviesii & $\mathrm{R}$ & F & $\mathrm{R}$ & $\mathrm{F}$ & $\mathrm{F}$ & $\mathrm{F}$ \\
\hline
\end{tabular}




\begin{tabular}{l|c|c|c|c|c|c}
\hline Reticulofenestra cf. daviesii & & & & & $\mathrm{F}$ & $\mathrm{R}$ \\
\hline Reticulofenestra dictyoda & $\mathrm{F}$ & $\mathrm{C}$ & $\mathrm{A}$ & $\mathrm{C}$ & $\mathrm{C}$ & $\mathrm{F}$ \\
\hline Reticulofenestra hillae & $\mathrm{R}$ & & $\mathrm{R}$ & $\mathrm{F}$ & $\mathrm{F}$ & $\mathrm{A}$ \\
\hline Reticulofenestra lockeri & $\mathrm{F}$ & $\mathrm{C}$ & $\mathrm{F}$ & $\mathrm{F}$ & $\mathrm{A}$ & $\mathrm{R}$ \\
\hline Reticulofenestra reticulata & $\mathrm{A}$ & $\mathrm{A}$ & $\mathrm{A}$ & $\mathrm{A}$ & $\mathrm{A}$ & $\mathrm{A}$ \\
\hline Reticulofenestra spp. (<3) & $\mathrm{R}$ & $\mathrm{A}$ & $\mathrm{A}$ & $\mathrm{A}$ & $\mathrm{A}$ & $\mathrm{F}$ \\
\hline Reticulofenestra erbae & $\mathrm{A}$ & $\mathrm{A}$ & $\mathrm{A}$ & $\mathrm{A}$ & $\mathrm{A}$ & $\mathrm{F}$ \\
\hline Reticulofenestra umbilica & $\mathrm{F}$ & $\mathrm{F}$ & $\mathrm{C}$ & $\mathrm{C}$ & $\mathrm{C}$ & $\mathrm{A}$ \\
\hline Sphenolithus cf. furcatolithoides & & $\mathrm{R}$ & $\mathrm{F}$ & $\mathrm{C}$ & $\mathrm{R}$ & $\mathrm{F}$ \\
\hline Sphenolithus moriformis & $\mathrm{F}$ & $\mathrm{F}$ & $\mathrm{R}$ & $\mathrm{F}$ & $\mathrm{F}$ & $\mathrm{R}$ \\
\hline Sphenolithus predistentus? & & $\mathrm{R}$ & & & & $\mathrm{R}$ \\
\hline Sphenolithus spiniger & & & & & & $\mathrm{R}$ \\
\hline Thoracosphaera spp. & $\mathrm{R}$ & $\mathrm{R}$ & $\mathrm{R}$ & $\mathrm{F}$ & $\mathrm{R}$ & $\mathrm{C}$ \\
\hline Zygrablithus bijugatus & $\mathrm{C}$ & $\mathrm{F}$ & $\mathrm{C}$ & $\mathrm{F}$ & $\mathrm{F}$ & $\mathrm{C}$ \\
\hline
\end{tabular}

Row count

\begin{tabular}{l|c|c|c|c|c|c}
\hline Reticulofenestra daviesii & 2 & 3 & 2 & 4 & 3 & 4 \\
\hline Reticulofenestra dictyoda & 4 & 7 & 13 & 6 & 8 & 5 \\
\hline Reticulofenestra hillae & 1 & 0 & 2 & 3 & 3 & 4 \\
\hline Reticulofenestra lockeri & 3 & 10 & 5 & 5 & 11 & 4 \\
\hline Reticulofenestra reticulata & 16 & 19 & 13 & 15 & 14 & 20 \\
\hline Reticulofenestra erbae & 12 & 26 & 20 & 12 & 20 & 5 \\
\hline Reticulofenestra spp. (<3) & 2 & 21 & 19 & 27 & 50 & 76 \\
\hline Reticulofenestra umbilica & 3 & 4 & 7 & 10 & 6 & 7 \\
\hline Sphenolithus moriformis & 4 & 5 & 2 & 3 & 3 & 4 \\
\hline Sphenolithus predistentus & 0 & 1 & 3 & 6 & 1 & 7 \\
\hline Sphenolithus spiniger & 0 & 0 & 0 & 0 & 0 & 2 \\
\hline Thoracosphaera spp. & 2 & 2 & 1 & 5 & 2 & 2 \\
\hline Zygrablithus bijugatus & 7 & 4 & 8 & 5 & 5 & 2 \\
\hline Blackites spinosus & 3 & 6 & 11 & 4 & 5 & 11 \\
\hline Blackites morionum & 0 & 0 & 0 & 0 & 1 & 2 \\
\hline Reticulofenestra cf. daviesii & 0 & 0 & 0 & 0 & 3 & 10 \\
\hline Discoaster 5-ray knob & 0 & 0 & 0 & 0 & 3 & 0 \\
\hline Helicosphaera bramlettii & 7 & 6 & 10 & 9 & 1 & 0 \\
\hline Helicosphaera wilcoxii & 0 & 1 & 3 & 0 & 0 & 0 \\
\hline Braarudosphaera bigelowii & 2 & 1 & 0 & 0 & 0 & 0 \\
\hline Isthmolithus recurvus & 0 & 2 & 0 & 0 & 0 & 0 \\
\hline \multicolumn{1}{c|}{ Species richness } & 27 & 33 & 33 & 29 & 36 & 39 \\
\hline
\end{tabular}

Count percentage

\begin{tabular}{l|c|c|c|c|c|c}
\hline Discoaster tanii & 0.333333 & 0.662252 & 0.311526 & 0 & 0 & 0.278552 \\
\hline Ericsonia formosa & 2.333333 & 2.317881 & 0.623053 & 2.95082 & 2.523659 & 1.114206 \\
\hline Helicosphaera compacta & 1.666667 & 0.331126 & 0.934579 & 0.327869 & 0.630915 & 0.557103 \\
\hline
\end{tabular}




\begin{tabular}{|c|c|c|c|c|c|c|}
\hline Helicosphaera reticulata & 0 & 0.331126 & 0.623053 & 0.983607 & 0 & 0.278552 \\
\hline Hughesius tasmaniae & 0 & 0 & 0 & 0 & 0 & 0.278552 \\
\hline Lanternithus minutus & 2.333333 & 1.324503 & 1.246106 & 1.967213 & 0.946372 & 0.835655 \\
\hline Neococcolithes dubius & 0 & 0 & 0.934579 & 0.655738 & 0.630915 & 0.835655 \\
\hline Cyclococcolithina protoannula & 1.333333 & 0.993377 & 2.492212 & 1.639344 & 2.208202 & 2.506964 \\
\hline Pontosphaera exilis & 0 & 0 & 0 & 0 & 1.26183 & 1.671309 \\
\hline Pontosphaera panarium & 0 & 0 & 0 & 0.327869 & 0.315457 & 1.392758 \\
\hline Pontosphaera multipora & 0 & 0.331126 & 0.623053 & 0.655738 & 1.577287 & 1.114206 \\
\hline Reticulofenestra bisecta & 17.66667 & 0.662252 & 1.246106 & 0 & 2.208202 & 1.949861 \\
\hline Reticulofenestra daviesii & 0.666667 & 0.993377 & 0.623053 & 1.311475 & 0.946372 & 1.114206 \\
\hline Reticulofenestra dictyoda & 1.333333 & 2.317881 & 4.049844 & 1.967213 & 2.523659 & 1.392758 \\
\hline Reticulofenestra hillae & 0.333333 & 0 & 0.623053 & 0.983607 & 0.946372 & 1.114206 \\
\hline Reticulofenestra lockeri & 1 & 3.311258 & 1.557632 & 1.639344 & 3.470032 & 1.114206 \\
\hline Reticulofenestra reticulata & 5.333333 & 6.291391 & 4.049844 & 4.918033 & 4.416404 & 5.571031 \\
\hline Reticulofenestra erbae & 4 & 8.609272 & 6.23053 & 3.934426 & 6.309148 & 1.392758 \\
\hline Reticulofenestra spp. $(<3)$ & 0.666667 & 6.953642 & 5.919003 & 8.852459 & 15.77287 & 21.16992 \\
\hline Reticulofenestra umbilica & 1 & 1.324503 & 2.180685 & 3.278689 & 1.892744 & 1.949861 \\
\hline Sphenolithus moriformis & 1.333333 & 1.655629 & 0.623053 & 0.983607 & 0.946372 & 1.114206 \\
\hline Sphenolithus predistentus & 0 & 0.331126 & 0.934579 & 1.967213 & 0.315457 & 1.949861 \\
\hline Sphenolithus spiniger & 0 & 0 & 0 & 0 & 0 & 0.557103 \\
\hline Thoracosphaera spp. & 0.666667 & 0.662252 & 0.311526 & 1.639344 & 0.630915 & 0.557103 \\
\hline Zygrablithus bijugatus & 2.333333 & 1.324503 & 2.492212 & 1.639344 & 1.577287 & 0.557103 \\
\hline Blackites spinosus & 1 & 1.986755 & 3.426791 & 1.311475 & 1.577287 & 3.064067 \\
\hline Blackites cf. morionum & 0 & 0 & 0 & 0 & 0.315457 & 0.557103 \\
\hline Reticulofenestra cf. daviesii & 0 & 0 & 0 & 0 & 0.946372 & 2.785515 \\
\hline Discoaster 5-ray knob & 0 & 0 & 0 & 0 & 0.946372 & 0 \\
\hline Helicosphaera bramlettii & 2.333333 & 1.986755 & 3.115265 & 2.95082 & 0.315457 & 0 \\
\hline Helicosphaera wilcoxii & 0 & 0.331126 & 0.934579 & 0 & 0 & 0 \\
\hline Braarudosphaera bigelowii & 0.666667 & 0.331126 & 0 & 0 & 0 & 0 \\
\hline Isthmolithus recurvus & 0 & 0.662252 & 0 & 0 & 0 & 0 \\
\hline
\end{tabular}

Appendix B. Species list recorded in the Rashrashiyah Formation. Taxa are alphabetically arranged with references

Blackites morionum (Deflandre in Deflandre \& Fert,1954) Varol, 1989

Blackites spinosus (Deflandre \& Fert, 1954) Hay \& Towe, 1962

Braarudosphaera bigelowii (Gran \& Braarud 1935) Deflandre, 1947

Chiasmolithus grandis (Bramlette \& Riedel, 1954) Radomski, 1968

Chiasmolithus oamaruensis (Deflandre, 1954) Hay et al., 1966

Clausicoccus subdistichus (Roth \& Hay in Hay et al., 1967) Prins, 1979

Coccolithus eopelagicus (Bramlette \& Riedel, 1954) Bramlette \& Sullivan, 1961

Coccolithus pelagicus (Wallich 1877) Schiller, 1930

Cruciplacolithus cruciformis (Hay \& Towe, 1962) Roth, 1970

Cyclicargolithus floridanus (Roth \& Hay, in Hay et al., 1967) Bukry, 1971

Cyclicargolithus floridanus $<5 \mu \mathrm{m}$ (Roth \& Hay, in Hay et al., 1967) Bukry, 1971

Cyclococcolithina protoannula Gartner 1971

Coccolithus formosus (Kamptner, 1963) Wise, 1973

Discoaster barbadiensis Tan, 1927 
Discoaster deflandrei Bramlette \& Riedel, 1954

Discoaster saipanensis Bramlette \& Riedel, 1954

Discoaster tanii Bramlette \& Wilcoxon 1967

Helicosphaera bramlettei (Müller, 1970) Jafar \& Martini, 1975

Helicosphaera compacta Bramlette \& Wilcoxon, 1967

Helicosphaera reticulata Bramlette \& Wilcoxon, 1967

Helicosphaera wilcoxii (Gartner, 1971) Jafar \& Martini, 1975

Hughesius tasmaniae (Edwards and Perch-Nielsen, 1975) de Kaenel and Villa, 1996

Isthmolithus recurvus Deflandre in Deflandre and Fert, 1954

Lanternithus minutus Stradner, 1962

Neococcolithes dubius (Deflandre in Deflandre and Fert, 1954) Black, 1967

Pontosphaera exilis (Bramlette \& Sullivan, 1961) Romein, 1979

Pontosphaera multipora (Kamptner, 1948 ex Deflandre in Deflandre \& Fert, 1954) Roth, 1970

Pontosphaera panarium (Deflandre in Deflandre \& Fert, 1954) Aubry, 1986

Reticulofenestra bisecta (Hay, Mohler and Wade, 1966) Roth, 1970

Reticulofenestra daviesii (Haq, 1968) Haq, 1971

Reticulofenestra cf. daviesii (Haq, 1968) Haq, 1971

Reticulofenestra dictyoda (Deflandre in Deflandre \& Fert, 1954) Stradner in Stradner \& Edwards, 1968

Reticulofenestra erbae (Fornaciari et al., 2010) Bown \& Newsam 2017

Reticulofenestra hillae Bukry \& Percival, 1971

Reticulofenestra lockeri Müller, 1970

Reticulofenestra reticulata (Gartner \& Smith, 1967) Roth \& Thierstein, 1972

Reticulofenestra spp. $(<3 \mu \mathrm{m})$ Hay, Mohler \& Wade, 1966

Reticulofenestra umbilica (Levin, 1965) Martini \& Ritzkowski, 1968

Sphenolithus cf. furcatolithoides Locker, 1967

Sphenolithus moriformis (Brönnimann \& Stradner, 1960) Bramlette \& Wilcoxon, 1967

Sphenolithus predistentus? Bramlette \& Wilcoxon, 1967

Sphenolithus spiniger Bukry, 1971

Thoracosphaera spp. Kamptner 1927

Zygrablithus bijugatus (Deflandre in Deflandre and Fert, 1954) Deflandre, 1959 